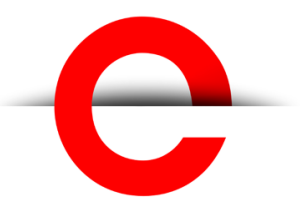

U T S

e PRES S
International

Research Network on Organizing by Projects (IRNOP) 2017

11-14 June 2017

(C) 2018 by the author(s). This is an Open Access article distributed under the terms of the Creative Commons Attribution 4.0 International (CC BY 4.0) License (https:// creativecommons.org/licenses/ by/4.0/), allowing third parties to copy and redistribute the material in any medium or format and to remix, transform, and build upon the material for any purpose, even commercially, provided the original work is properly cited and states its license.

Citation: Sabini, L., Muzio, D. and Alderman, N. 2017 Integrating sustainability into project management practices: the perspective of professional institutions. International Research Network on Organizing by Projects (IRNOP) 2017, UTS ePRESS, Sydney: NSW, pp. 1-17. https:// doi.org/10.5130/ pmrp. irnop2017.5661

Published by UTS ePRESS | http://pmrp.epress.lib.uts. edu.au
CONFERENCE PAPER

\section{Integrating sustainability into project management practices: the perspective of professional institutions}

\author{
Luca Sabini ${ }^{*}$, Daniel Muzio², Neil Alderman ${ }^{3}$ \\ ${ }^{1}$ Hertfordshire University, Hatfield, UK \\ 2,3 Newcastle University Business School, Newcastle upon Tyne, UK
}

*Corresponding author: Luca Sabini, Hertfordshire University. luca.sabinianewcastle.ac.uk

Name: International Research Network on Organizing by Projects (IRNOP) 2017

Location: Boston University, United States

Dates: 11-14 June 2017

Host Organisation: Metropolitan College at Boston University

Dol: https://doi.org/10.5130/pmrp.irnop2017.5661

Published: 07/06/2018

\section{Abstract}

This paper is based on a work-in-progress research project; therefore, results and conclusions are preliminary.

\section{Synopsis}

Sustainability, in its broadest meaning, has acquired a great importance in modern society and consequently influences almost every aspect of social life. This paper analyses the transformation that the project management profession is undergoing towards the integration of sustainability into its core values and practices.

\section{Research design}

This research uses qualitative data from a mix of semi-structured interviews and archival evidence - professional bodies of knowledge, codes of ethics, newsletters, websites, social media platforms, blogs, online databases and international standards - with the intention of 
U T S

e PRES S

answering the following research question: what is the influence of professional associations with regard to the institutionalizing of sustainability practices into project management (PM) tools and techniques?

\section{Main findings}

Different players influence, in different ways, the PM profession. Our analysis reveals that the nature of these actors is very heterogeneous, and the influence of the professional world of PM on the institutionalization of sustainable project management (SPM) is manifested in the different actions carried on by the entities we highlighted above. Therefore, the shift towards SPM is the result of the combination of each actor's individual strategy (Muzio, Brock \& Suddaby 2013).

\section{Research Implications}

The analysis of sustainable project management (SPM) is aimed at contributing to the PM academic literature, describing the transformation of PM practices, and to the practitioner literature, engaging with PM professional associations on the way they introduce the set of new practices.

\section{Keywords}

\section{Sustainability, Project Management, Professional Associations}

\section{Introduction}

In the news, undoubtedly a growing attention is being paid to anything connected with sustainability initiatives. ${ }^{1}$ Moreover, a strong connection with project management (PM) is also evident from a review of academic publications (Brones, Carvalho \& Zancul 2014; Chofreh et al. 2015; Fernández-Sánchez \& Rodríguez-López 2010; Marcelino-Sádaba, GonzalezJaen \& Perez-Ezcurdia 2015; Martens \& Carvalho 2015, 2016; Sabini 2013, 2016; Sabini \& Muzio 2017; Sánchez 2015; Silvius \& Schipper 2014) or by looking at the publications and announcements of the PM professional associations (IPMA 2015a; PMI 2011, 2016). In addition, there is also a set of new, and non-traditionally established, associations, such as Green Project Management (GPM 2016), and international entities, such as the United Nations Office for Project Services (UNOPS), which are also contributing to the development of new sets of tools and techniques to make projects more sustainable.

Given the importance of projects in modern society, ${ }^{2}$ it is to be anticipated that the PM profession will experience a growing pressure from society to balance social, environmental and economic interests in projects. This is happening even more powerfully since the link between

\footnotetext{
1 See the websites of major newspapers, which permanently host a section with these themes on their homepage, e.g. BBC news has a "Science \& Environment" section (http://www.bbc.co.uk/news/science and_environment); The Telegraph has a "Science" section (http://www.telegraph.co.uk/science); The Guardian has a "Sustainability case studies" section (https://www.theguardian.com/sustainable-business/ ng-interactive/2015/may/13/guardian-sustainable-business-awards-sustainability-case-studies-database); and The Economist has a "Science and technology" section (http://www.economist.com/sections/sciencetechnology).

2 "One-third of the worldwide gross domestic product (GDP) in society is initiated by projects" (Turner, Huemann \& Bredillet 2010) cited in (Eskerod \& Huemann 2013, p. 44).
} 
sustainability and PM (henceforth SPM) has grown in importance (Silvius \& Schipper 2014). Something similar can be observed to have happened to the engineering profession, which has "begun to recognise its larger role in the environmental field and environmental policies" (Boyle 1999, p. 85). For engineers, it was a slow process of incorporating "environmental ethics" (Saad 1997) within all aspects of professional engineering as an essential component of the professional accreditation process.

Comparably, induced by a set of different actors (and primarily the professional associations), a pressure on PM is arising to recognize sustainability as part of PM professional DNA. This acknowledgement is leading slowly to a process of redefinition of PM professional traits (such as considering longer-term effects of projects), in a similar manner to that experienced in the engineering profession. This raises the importance of professional institutions and their position in injecting and disseminating new practices that are sustainability related. Indeed, regulatory agencies, such as professional associations, are "critically important in the theorization process because they enable the formation and reproduction of shared meanings and understandings" (Greenwood, Suddaby \& Hinings 2002, p. 61). This means that professional associations can "legitimate change" either by fostering the discourse on sustainability themes (holding conferences and events, issuing newsletters, etc.), or by "reframing professional identities as they are presented to others outside the profession" (Greenwood et al. 2002, p. 59), such as awarding sustainability-oriented professional qualifications.

In this research, we argue that to integrate sustainability in PM, inputs from a broad ecology of actors (in which PM professional associations have a pivotal role) are needed. Therefore, we describe strategies and actions that the PM professional world is carrying out to integrate sustainability into PM. In particular, having collected a large amount of evidence (factual data through archival analysis, backed up by key players' opinions, through semi-structured interviews), we describe the governing mechanisms different actors use to impact the PM profession.

\section{Professional associations and other institutional agents}

In this study, we apply Scott's $(1995,2008)$ theoretical framework to explain institutional pressure on organizations. He identifies analytically the three "pillars" which constitute a framework to determine institutional pressure on organizations. This framework stresses that, "although institutional elements - rules, norms, beliefs - are primarily symbolic in nature, to be of interest these symbols must impact social behaviour: they must be reflected in activities, relations, and resources" (Scott 2008, p. 222). Consequently, every institution is an expression of diverse elements (in Scott's terminology: "pillars") "that depend on different bases of compliance, employ varying mechanisms, evoke differing logics of action, are signaled by different indicators, and offer multiple bases for determining legitimacy" (Scott 1995, chap. 3).

These 'pillars' are grouped into three sets: the regulative, the normative, and the culturalcognitive. The regulatory pillar originates in coercive power from State laws and rules. The normative pillar relies on those 'social' or 'moral' obligations which are not strictly enforced by a law. Those obligations advocate a given set of behaviours, which are morally sanctioned if not reproduced in a 'legitimate' way. The cultural-cognitive pillar emphasizes those taken for granted or 'orthodox' conceptions which individuals assign to reality to make sense of it.

Therefore, drawing a parallel with the study of Scott et al. (2000), where pressure coming from a different set of institutional actors changed the traditionally established professional governance in healthcare in the San Francisco Bay area, we describe how different PM professional actors are influencing the shift of the PM profession towards sustainability. 
In our analysis, we categorized actors' actions according to cultural-cognitive and normative pillars only, as regulatory elements tend to be non-existent. As highlighted briefly before, the regulatory pillar originates in coercive power from state sanctions, and PM is not subject to such sources of influence at present. This is because PM is a non-mandatory profession, and therefore it is not subject to or backed up by state laws and regulations. On the other hand, the normative pillar relies on "social" or "moral" obligations that are not strictly enforced by law but have to be complied with if a project manager is to be considered part of the profession. In our sample, actions displaying this element include professional codes of ethics which embrace SPM, the formal endorsement of international standards on sustainability and the creation of bespoke standards and certifications on SPM. Lastly, the cultural-cognitive pillar emphasizes those taken for granted or "orthodox" conceptions reflective of a recurring professional issue or theme. This suggests the use of "common schemas, frames, and other shared symbolic representations that guide behaviour" (Scott 2008, p. 222). Therefore, actors display these elements when they are involved in advertising SPM or organizing conferences and meetings with a focus on SPM or build training programs for SPM. These actions are oriented towards building a shared idea of what SPM is and how it could and should be integrated into PM practices.

In this way, we broaden the meaning of what Greenwood et al. (2002) label as "regulatory agencies." As such, professional associations (established and new ones), consultants, communities of practice, universities, public entities and individuals constitute the kind of "regulatory agents" that can "legitimate change by hosting a process of discourse through which change is debated and endorsed" (Greenwood et al. 2002, p. 59). The way they make sense of sustainability and PM and the pressure they exert on PM, as stakeholders with different (and sometimes conflicting) interests, determine the developmental trajectory PM will undertake.

In the following sections of the paper, we describe how institutions apply strategies and mediate interactions among the different actors involved (Muzio \& Faulconbridge 2013; Sabini 2014), with the aim of defining the development of the topic of "sustainability" among PM practices.

\section{Methodology/data collection}

This research was conducted in two separate temporal stages, mixing two kinds of data sources: semi-structured interviews and archival data.

In the first stage, we have conducted 14 semi-structured interviews, in the time span from May 2015 to September 2016. Respondents occupied key positions within a number of both new and established professional PM associations (see Table 1).

Table $1 \quad$ Interviews held with different PM associations key people

\begin{tabular}{|l|c|}
\hline Name of Professional Association & $\begin{array}{c}\text { Number of } \\
\text { Interviews }\end{array}$ \\
\hline Association of Project Management & 4 \\
\hline Project Management Institute & 4 \\
\hline International Project Management & 1 \\
\hline Association & 1 \\
\hline Green Project Management & 1 \\
\hline EarthPM & 3 \\
\hline PMI Community of Practice
\end{tabular}


The interviews followed a standard protocol, lasted between 30 and 90 minutes, and were recorded, transcribed, anonymized and entered into NVivo11 for the subsequent analysis. The general interview outline (Appendix 1) presents questions that were designed to highlight the interviewees' point of view on sustainability, the strategic decisions that they had recently faced in the PM profession relating to SPM, relationships with other actors and issues and obstacles that they experienced regarding SPM.

In the second stage, we performed an archival analysis (from September to December 2016) verifying through factual data the elements which emerged from the semi-structured interviews. We examined documents from professional associations' websites, blogs, newsletters, social media and so on to make sense of the growing importance of SPM within PM discourses. This resulted in the identification of 78 activities performed by professional and non-professional agents; these records have been ordered into a spreadsheet database, and each record is then referenced with respect to its line number (e.g. something which referred to an APM action is labelled as "line 4-APM").

\section{DATA ANALYSIS}

Following others researches (Muzio \& Faulconbridge 2013), we coded the data according to Scott's (1995) institutional framework.

Table 2 Actions towards SPM undertaken by different entities grouped by their normative and cognitive element

\begin{tabular}{|c|c|c|}
\hline $\begin{array}{l}\text { Type of } \\
\text { Action }\end{array}$ & Action & Actor/Entity \\
\hline \multirow{4}{*}{ Normative } & Code of Ethics & Professional associations \\
\hline & $\begin{array}{l}\text { Endorsing international } \\
\text { standards }\end{array}$ & Professional associations \\
\hline & $\begin{array}{l}\text { Issuing SPM focused or SPM } \\
\text { related standards }\end{array}$ & $\begin{array}{l}\text { Social movements, international } \\
\text { bodies }\end{array}$ \\
\hline & Issuing SPM certifications & Social movements, consultants \\
\hline \multirow{5}{*}{ Cognitive } & Advertising SPM & $\begin{array}{l}\text { Professional associations, } \\
\text { social movements, consultants, } \\
\text { communities of practice, public } \\
\text { entities, individuals }\end{array}$ \\
\hline & $\begin{array}{l}\text { Conferences focusing on } \\
\text { SPM }\end{array}$ & $\begin{array}{l}\text { Professional associations, social } \\
\text { movements, communities of practice }\end{array}$ \\
\hline & Meetings on SPM & $\begin{array}{l}\text { Professional associations, } \\
\text { consultants }\end{array}$ \\
\hline & Trainings on SPM & $\begin{array}{l}\text { Universities, consultants, social } \\
\text { movements }\end{array}$ \\
\hline & Other SPM related events & Communities of practice \\
\hline
\end{tabular}

This framework allows us to categorize actions according to their displayed cognitive, normative, and regulative element (Scott 1995). In this way, recognizing if an action is legally forced (regulative), is a social obligation (normative) or is a taken-for-granted way of doing things (cognitive), we can group actors' actions into different categories. These actions are illustrated in table 1 , where the action and the actors performing it have been associated with 
the type of institutional action (normative or cognitive). As is evident from the table, and as we highlighted in the second section, the regulatory element is missing.

The archival data have been organized in a database according to the actor performing the action ("PM professional associations", "non-established professional associations", "Individuals", "Communities of practices", "Consultants", "Public entities", "International bodies" and "Universities"), a brief description, a date, an illustrative quote from data and a web link. Where possible, we also coded archival data with codes derived from the interviews in order to support practitioners' opinions with factual data.

The result of this two-stage data collection and analysis resulted in the production of an empirical narrative to reveal actors involved in influencing the shift towards SPM and their weight behind this shift. Although the interviews were coded according to a grounded style approach, we decided to discuss findings following Scott's (2008) institutional framework, which allows us to place actors and actions according to their normative and cultural-cognitive elements.

Summarizing, the analysis revealed the importance of professional associations (established and new ones) in the shift of PM towards SPM; this happens despite external pressures coming from the society. Therefore, the following sections highlight forces pushing change (PM associations and other actors) and their respective actions.

\section{Forces pushing change}

Different players influence, in different ways, the PM profession. Our analysis reveals that the nature of these actors is very heterogeneous, ranging from individuals (acting as a "guru") to associations at different levels (national chapters and corporate levels) and also to public bodies (government agencies such as the Cabinet Office in the UK) and international bodies (such as ISO committees). Therefore, we identified the actors in play in a deductive from archival data, looking at actors' actions and ways in which these actors push the change towards SPM.

However, to introduce each of the actors, we decided to divide them into two sets: PM professionals and "other actors." The first set includes people which work as PM professionals. The second set includes all those actors that are not in the PM world, but have some sort of relationship with it (individuals, consultants, public entities, international bodies and universities).

\section{PM PROFESSIONALS}

This section describes the SPM in relation to the influence exerted by the associations' world, which is composed mainly by traditionally established and new PM associations.

When introducing corporate-level PM professional associations, national chapters and non-established associations, an important contrast has to be underlined. Indeed, the landscape of PM associations with regard to SPM is characterized by the contraposition between established (PMI and IPMA) and more recent (GPM, EarthPM) associations. The second group is characterized by several associations, ranging considerably in size, which have been created with the express focus to tackle sustainability (see EarthPM and GPM mission statements later in this section).

Therefore, in the first sub-section are grouped the established PM professional associations (PMI and IPMA), their national chapters (the APM, IPMA Netherland, PMI - California, PMI France, PMI-USA), their communities of practice (PMI - Project Management Global 
Sustainability); and in the second sub-section, recently established professional associations (EarthPM and GPM) have been described.

Looking first at traditional associations, the two largest traditional PM associations with the most widespread membership are PMI (Project Management Institute) and IPMA (International Project Management Association) with their numerous national chapters and, according to collected evidences from the archival analysis, their main activities are related to "advertising" SPM. This action is aimed purely at reporting news and signalling advancement on SPM practices. Indeed, to make the point, articles (Gareis, Huemann \& Martinuzzi 2009; Gareis et al. 2011) a book (Gareis, Huemann \& Martinuzzi 2013; p. X; line 46, PMI), a white paper (PMI 2011), a website definition (PMI 2016) and an annual report (PMI 2013) have been recognized. Basically, in this way there is a recognition that the topic is of rising importance, but without any direct action to amend PM practices. This recognition occurs also at a national level with the APM in the UK, which acknowledges publicly on its website how projects need to consider sustainability (line 4-APM) and promotes several case studies that highlight SPM (line 7, 8,9-APM). Similarly, the IPMA Netherlands has adopted a motto inspired by SPM: "Better projects for a better world" (line 36 - IPMA Netherlands).

PMI and IPMA are not just involved in advertising mechanisms, but also demonstrate a desire to have a direct influence on SPM by organizing conferences and endorsing standards.

Interestingly, on the "conference" side, IPMA organized the "IPMA Research Conference" on PM and sustainability with an explicit focus to "shed light on the obstacles [to sustainability]". Furthermore, looking at IPMA's new "Individual" (IPMA 2015c), 3 "Project" (IPMA 2016b) ${ }^{4}$ and "Organizational" (IPMA 2016a) ${ }^{5}$ competence baselines, it is possible to note how they all refer in some way to SPM.

PMI has also (through one of its chapters) endorsed the UN Global Compact, which is considered "the world's largest corporate sustainability initiative" (www.unglobalcompact.org). The chapter declared that it "supports the ten principles of the Global Compact with respect to human rights, labor, environment and anti-corruption" (line 59 - PMI France). Moreover, other PMI national chapters host meetings on the topic of sustainability in general or on SPM in particular. One notable example is the PMI - California with "I'm a Project Manager - Is Sustainability My Problem?” in 2016 (line 53 - PMI California 2016).

Perhaps the most important sign of professional associations' engagement in SPM is the creation of communities of practice $(\mathrm{CoP})$ and special interest groups (SIG). CoPs and SIGs represent a number of individuals who are engaged in sustainability and advertise SPM (line 49 - PMI CoP 2008) or organize events (line 37 - PMI CoP 2011). Individuals in these groups express their vision on SPM though articles in PM association blogs (line 32, 33, 34 IPMA blog 2016), ${ }^{6}$ social media (line 78 - list of LinkedIn groups 2016) and books (Taylor

3 "Identify, and ensure that the portfolio complies with relevant sustainability principles and objectives" (IPMA 2015c, p. 298).

4 “We now expect every excellent project to consider sustainability and the environment with a long-term perspective, not as an option but rather as the default" (IPMA 2016b, p. 47)

5 “Describes the concept of organizational competence and how this should be used to deliver organization's vision, mission and strategic objectives in a sustainable manner" (IPMA 2016a, p. Executive Summary)

6 "They all need to be managed in a coordinated way from a long-term perspective"; "This is why sustainability and resilience will be key concepts to be considered for the way we manage our projects"; "It also deals with the responsibility of project managers towards the wider society, including sustainability and the environment" (IPMA blog 2016 - lines 32, 33, 34). 
2011, 1. line 10). These tools create the possibility for project managers to exert an influence on SPM outside of the strict control of the corporate level of the professional associations.

The second category, in contrast the first, is comprised of new and/or informal associations. Under this label, we group new associations (i.e. GPM - Green Project Management), social movements (i.e. EarthPM) and online groups ${ }^{7}$ which have been established with the explicit intent of tackling SPM or sustainability in general.

Non-established professional associations such as GPM and EarthPM (both founded in 2009), as with more established ones, promote SPM in many ways. This seems to be quite normal, since their mission is "at the intersection of Sustainability and Project Management" and they have been established "to advance sustainability in Project Management" (GPM website 2016).

Nonetheless, pushing forwards respect to traditional and established PM associations, new ones advance SPM by developing bespoke SPM standards, methodologies, certifications and courses. GPM issued the "GPM ${ }^{\circledR}$ P5 ${ }^{\mathrm{TM}}$ Standard for Sustainability in Project Management" (line 77 - GPM), which provides a measurable framework for projects useful for sustainability reporting. This bespoke standard "is a tool that supports the alignment of Portfolios, Programs, and Projects with organizational strategy for Sustainability" (GPM 2016, p. 13). Additionally, GPM issued in 2013 a process-based, structured methodology for managing change, the "PRiSM."This methodology helps organizations to change towards P5 standard as it underlines areas of "sustainability and integrates them into the traditional core project phases to reduce negative environmental and social impacts in all project types using the GPM P5 Standard" (Carboni, González \& Hodgkinson 2013, 1., line 73).

Moreover, training courses have been set by EarthPM and GPM to improve project managers' abilities in SPM ("Distinguish yourself! Get certified in Green Project Management" - line 18 - EarthPM 2012 and “GPM ${ }^{\circledR}$ Certification, PRiSM methodology" line 19, 74 - GPM 2012). And also, very often, these courses end up with SPM certifications ("Earning the GPM ${ }^{\mathrm{TM}}$ Certification puts you in a special league, positioning you as a change agent with the know-how to apply sustainable methods to projects" - line 75 - GPM).

Another method non-established associations use to spread SPM tools that they have developed is through collaboration with universities. They build masters' programmes partnerships to "provide institutes of higher learning with a turnkey sustainable project management program that can be utilized for undergraduate, masters, or continuing education" (line 22, 23 - GPM).

The underlying idea for non-established associations is the marketization of tools they develop. Indeed, to sustain themselves, these associations need to supply their products to a wide set of individual, organizational and institutional actors ("we can help you cultivate value from sustainability" line 20 - GPM 2012).

\section{OTHER ACTORS}

In addition to actors strictly involved in PM, a multitude of different actors make an impact on the profession. Among actors which exert an influence towards SPM are listed consultants (e.g. APMG International, LIFE Academy, MIT/Sloan \& BCGroup report, SustainAbilities,

7 I.e. Green Project Managers, Boston Area Sustainability Group (BASG), GreenBiz.com, Project Management and Global Sustainability, Sustainability Career Group, IISPM, Sustainable Business Management, Sustainability Professionals. 
Sustainability Learning Centre, Sustainable Measures, The Economist, Isos Group), public entities (i.e. AXELOS, Cabinet Office, Office of Government Commerce, Salix Finance), international bodies (e.g. United Nations and ISO) and universities (e.g. Aberdeen University, Lille University, Malmo University).

Similar to PM professional associations, this set of actors pushes ahead its interests towards SPM with different strategies. Above all there is what we called before "advertising SPM," which is fulfilled mainly by consultants (through blogs and online articles, database line 64 Sustainable Measures database line 69 - ISOS Group, 2016) and public entities (providing examples of best practices in public projects database line 14 - CabinetOffice, 2012).

Moreover, among the several strategies this set of actors put in place are also activities which indirectly affect SPM, such as sustainability conferences ("The Sustainability Summit 2017" line 68 - The Economist, 2017), certifications ("Project Management for Sustainable Development - PM4SD ${ }^{\mathrm{TM}}$ - is a specialised certification scheme for Project Managers working in the tourism sector" line 12 - APMG International), training (Master in "Project Management and Sustainability, line 67 - Malmo University), courses (see the online course "Green/Sustainability Project Management" (line 63 - SustainabilityLearningCenter, 2014) and standards (see ISO 21500 "Guidance on PM": "The benefit is to use the resources deployed in the most efficient way, or reaching more with less resources”, line 39 - ISO 2012).

\section{Strategies adopted}

The influence of the professional world of PM on the institutionalization of SPM is manifested in the different actions carried on by the entities we highlighted above. Therefore, the shift towards SPM is the result of the combination of each actor's individual strategy (Muzio, Brock \& Suddaby 2013).

As anticipated, to describe the set of actions undertaken by professional actors we decided to use Scott's (1995) institutional framework. Some actors (i.e. professional associations, social movements and consultants) issue both normative (e.g. endorsing sustainability standards, developing codes of ethics which include SPM, etc.) and cognitive (e.g. advertising SPM, organizing conferences, meeting and trainings) actions, whereas others tend to issue actions belonging only to one institutional category (e.g. universities, communities of practice, public entities and individuals perform only actions with cognitive elements).

\section{ACTIONS DISPLAYING CULTURAL-COGNITIVE ELEMENTS}

Activities which display cognitive elements are those culturally supported values, beliefs and assumptions coming from a wide range of actors (see Figure 1). For instance, those focused on reporting news and signalling advancement of SPM practices are among the most widely diffused.

The process of advertising SPM ideas is led by a broad set of different actors, but with the common idea that "all kinds of work has to be directed or at least influenced by the concept of sustainability" (interview 6, PMI). PM professional associations, as well as consultants, public entities and individuals issue articles and carry out miscellaneous activities in order to raise awareness on this topic with the common underlying idea that "this is a big gap" (interview 13, EarthPM). Nonetheless, the acknowledgement of this "gap" in PM tools and techniques is seen as an expression of the newness of the topic ("I think that it is normal to have a gap exist when a topic is new and we can say that sustainability is quite a new topic in the project management arena" - interview 11, consultant). 
Indeed, PMI supported ways of advertising SPM concepts by sponsoring research which then materializes in articles (Gareis et al. 2009) and books (Gareis et al. 2013). Also IPMA, through its blogs (line 32, 33, 34 - IPMA blog 2016), ${ }^{8}$ social media (line 78 - list of LinkedIn groups 2016), and books (Taylor 2011) has similarly contributed to support SPM advance.

This range of activities acknowledges the importance of SPM as a topic but exhibits no intent to analyse the concept further, as in the example of a UK public-owned body (AXELOS) publishing an article complaining about the absence of implementation of SPM. ${ }^{9}$ This article is recognizing that "sustainability clearly has a link in many aspects of management and many aspects of work actually in general" (interview 6, PMI); nonetheless, it calls for further implementation in project and portfolio management techniques. Furthermore, a UK public entity (Cabinet Office) mentions sustainability in different parts of a construction strategy document (line 14 - Cabinet Office 2012) as a way to publicize its importance in the projects.

As demonstrated, PM professional associations are not the only actors who analyse SPM concepts, as a number of new PM associations and consultants also provide reports or offer examples on how SPM can be unpacked and examined in its key concept (e.g. consider sustainability issues in the beginning of every project, include all the stakeholders in key project decisions). Here the reasons to analyse SPM will be slightly different from those of the established professional associations. For this kind of actor, the intent is to set a market around some service they provide. One example is the Boston Consulting Group (BCG) Report on "Investing For a Sustainable Future" (Unruh et al. 2016), where it is explicitly underlined that "a growing number of investors are paying attention to $\mathrm{ESG}^{10}$ performance, as evidence mounts that sustainability-related activities are material to the financial success of a company over time" (line 54 - BCG 2013). In this document BCG provides a report on how corporate leaders should respond to the growing interest in sustainability. Another report worth mentioning is the one from EarthPM which, through examples of SPM practices, explores how some companies adopting SPM improved their overall performances (line 58 - EarthPM 2016).

\section{ACTIONS DISPLAYING NORMATIVE ELEMENTS}

Actions which display a normative element are those morally governed and originating as a part of a social obligation and are mainly performed by professional associations, social movements and consultants. PM professional codes of ethics which address sustainability, issuing bespoke SPM standards or endorsing international ones, are all examples of this kind of voluntary activity which is socially and ethically dictated.

Indeed, among the reasons for giving sustainability an impetus in public opinion (and therefore also to SPM), undoubtedly there is an intrinsic ethical concern. Sustainability, in pursuing "ecological health," "social equity," and "economic welfare," raises huge ethical

8 "They all need to be managed in a coordinated way from a long-term perspective"; "This is why sustainability and resilience will be key concepts to be considered for the way we manage our projects"; "It also deals with the responsibility of project managers towards the wider society, including sustainability and the environment" (IPMA blog 2016 - line 32, 33, 34)

9 "Project management forms a part of portfolio management and in both there is currently a lot of talk about the issue of sustainability but not a lot of implementing sustainability in portfolio management" (line 13, AXELOS 2005).

10 (Environmental, social and governance). 
challenges which are involved in its promotion and achievement. PM professional associations, social movements and consultants understood these social requirements and therefore issued direct actions to tackle them.

As per a common definition, ethics "seeks to address questions about morality, concepts like good and bad, right and wrong, justice, virtue, etc." (Moore 2012). Therefore, notions such as "good and bad" and "right and wrong" are embedded in ethics definition. These notions emerge very clearly from the discourse on sustainability in general: "organizations that separate the 'doing the right thing' from 'doing things right' tend to be more successful in the long term" (Gartner 2006), meaning that these two concepts are tied together. Consequently, in the world of PM, a strong connection between SPM and ethics it is also shared: "A project run with green intent is the right thing to do, but it will also help the project team do things right" (Maltzman \& Shirley 2010, p. 54).

Ethical concerns are implied even more often in practitioners' discourses when considering the importance of SPM and referring to it as "a more general thing that everyone should observe as something that's good for the world" (interview 1, APM). Again, the discourse abounds with ideas of "doing the right thing," and "if project managers have that responsibility or that power in our hands we should make good use of it" (interview 11, consultant). Concerns about ethics arise so strongly in some discourses that the conditions driving the project may lead to some ethical warnings, wherein it is suggested that the project manager has to decline from taking on the project: "It's a matter of principle, so if we think it's unsustainable in what they're doing, then as a matter of principle we might refuse the project to go any further" (interview 2, APM); also: "I try to teach my younger project managers that there are some projects you need to walk away from. And if you are unhappy about the ethics or you're unhappy about the sustainability issues, those are the things you should walk away from" (interview 1, APM).

PMI and IPMA identify SPM as part of their codes of ethics, advertising its main ideas publicly on their websites (line 34 - IPMA 2016, and line 50 - PMI 2016), and therefore recognizing that "there is a significant appetite for bringing sustainable principles into project management" (interview 1, APM). Furthermore, examining the presence of SPM in codes of ethics, it is revealing how strong the link between these two ideas is. Indeed, looking closely at the codes of ethics it is possible to find strong references to SPM. ${ }^{11}$ Interestingly, both the IPMA code and the PMI one, recognize the influence that projects have on "sustainability," but without mentioning the word explicitly, as only the three pillars of sustainability (environmental, social and economic) are named.

Among other morally governed actions, there is a notable example of PMI establishing a community of practice on SPM in 2010 (see the "Global Sustainability Community of Practice"). This community was founded with the aim to be recognized as the "global driving force for implementing Sustainability in Organizational PM" (line 37 - PMI). But, as seen before, there have been other ways for PMI to support SPM concepts as sponsoring research materialized in articles (Gareis et al. 2009) and books (Gareis et al. 2013). Furthermore, recently (beginning in 2017) even PMI national chapters have regional meetings making a business case out of SPM: "basic and advanced project management techniques will be

11 IPMA - “We recognize that our projects, programmes and project portfolios, affect people, society and the natural environment in various ways, both locally and globally" (IPMA 2015b).

$\mathrm{PMI}$ - "Ethics is about making the best possible decisions concerning people, resources and the environment" (line 56, PMI - Code of Ethics). 
compared to sustainable methods used by many companies to remain competitive" (line 60 - PMI New Hampshire). Another established PM professional association, IPMA, with meetings and events (see IPMA Research Conference in 2016 [line 29] and Global Young Crew Workshop 2016 [line 57]), is fostering the discourse over SPM aiming at understanding and clarifying its concepts.

Behind these activities there is the recognition that the topic is growing fast (it "is a critical societal imperative", line 37 - PMI Community of Practice 2011), and there is the need to understand the implications for the PM profession in terms of expectations and responsibilities attached to the profession ("improve how practitioners of all levels manage the complexity and dynamics of organizations, projects and programs" [line 46 - PMI 2013]).

\section{Conclusions}

To ultimately integrate sustainability into the PM profession, inputs from a broad ecology of actors are needed. This is the first conclusion that we draw from this analysis. While established PM professional associations (PMI and IPMA) play a pivotal role, influences from other actors (and especially non-established associations such as GPM and EarthPM) are fundamental.

In Figure 1, we describe actors from our sample, their interactions and their influence on the PM profession. In particular, this picture shows how different entities influence the PM profession with respect to SPM and which approaches they have implemented. This relationships map is derived from our evidence, and therefore its main limitation is that it is a preliminary and probably still incomplete picture of this field.

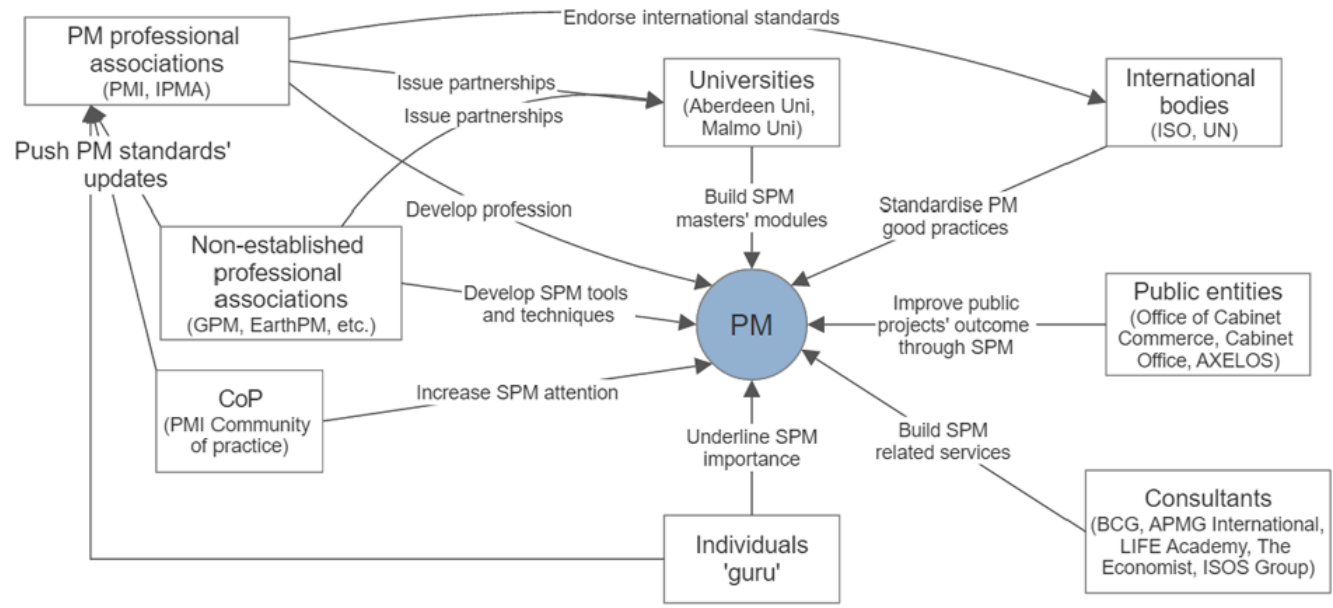

Figure 1 Actors and their relationships as "regulatory agents"

Indeed, some more detailed considerations from this analysis arise from the comparison between actions of established versus non-established associations. The first consideration relates to the overall strategy adopted by these actors; although non-established associations seem to have implemented an "active engagement" on the topic of SPM, the established ones are adopting more of a "wait-and-see" strategy. The second consideration is related to the way the topic of sustainability is dealt with. 


\section{ACTIVE ENGAGEMENT VS “WAIT AND SEE”}

A fundamental difference between new and established PM professional associations is in the aim of the association. Associations such as GPM or EarthPM have been created as a response to the need of practitioners for guidelines and best practices on how to implement sustainability metrics within everyday practices, whilst established associations have a broad approach to PM, such as its professional advancement and the improvement of project success (see PMI "Core purpose" and IPMA vision). ${ }^{12}$

Although both sets of institutions have some kind of strategy towards sustainability, the strategies they pursue are diametrically opposed. The newest associations usually tend to show an active engagement towards sustainability: creating bespoke standards (GPM 2016), producing monitoring methods (Carboni et al. 2013) and issuing related certifications (line 75 - 'GPM Certifications'). The established associations adopt more of a wait-and-see strategy, contemplating the importance of sustainability and raising their members' awareness of the issue, but with few actions adopted to tackle the issue in a practical way (IPMA 2015c, 2016a, 2016b).

\section{“SPLITTING' SUSTAINABILITY”}

Sustainability is a very broad concept, and it is difficult to tackle holistically. The idea itself can hardly be introduced into professional practices simply by introducing the word sustainability in the professional bodies of knowledge. Instead it can more easily be injected into professional core practices, slowly and gradually, following a progressive approach. PM professional associations are therefore adopting a low-risk strategy by embracing gradual and adaptive changes to their practices and objectives. As an example, looking at statements in the code of ethics, such as the IPMA code, pillars of sustainability are mentioned, but without using the word itself: "Our projects, programmes and project portfolios, affect people, society and the natural environment in various ways, both locally and globally" (IPMA 2015b).

Although it is necessary to recognize that the last IPMA competence baseline (the ICB4) has a paragraph on sustainability (6.3.3.4 "Identify, and ensure that the portfolio complies with relevant sustainability principles and objectives”- IPMA 2015a: 298), the well-known and most recognized PM body of knowledge, the PMBOK (2013), does not yet dedicate a section (or a paragraph) to it.

This reveals a cautious approach on the part of PM professional associations, which are concerned not to detract their members from other important responsibilities and constraints. Therefore, by introducing the concept of sustainability gradually, they recognize that the topic is important to the profession, but are not willing to turn upside down the set of techniques and standards that have been built during the development of the PM profession.

\section{References}

AXELOS, 2005, from footnote 12, p. 16.

Boyle, C. 1999, Education, sustainability and cleaner production, Journal of Cleaner Production, vol. 7, no. 1: pp.83-87. https://doi.org/10.1016/s0959-6526(98)00045-6

12 From the PMI strategic plan, the core values are "to advance the practice, science and profession of project management throughout the world in a conscious and proactive manner" (PMI 2012, p. 3); and from the IPMA vision: "Promoting competence throughout society to enable a world in which all projects succeed” (line 70, IPMA). 
U T S

e PRES S
Brones, F., Carvalho, M. M. de, \& Zancul, E. de S., 2014, Ecodesign in project management: a missing link for the integration of sustainability in product development? Journal of Cleaner Production, vol. 80, pp. 106-118. https://doi.org/10.1016/j.jclepro.2014.05.088

CabinetOffice, 2012, Government construction strategy. Retrieved from https://www.gov.uk/government/ uploads/system/uploads/attachment data/file/61151/GCS-One-Year-On-Report-and-Action-PlanUpdate-FINAL 0.pdf

Carboni, J., González, M., \& Hodgkinson, J., 2013, PRiSM@, Projects integrating sustainable methods, GPM Global.

Chofreh, A., Goni, F., Shaharoun, A. M., \& Ismail, S., 2015, A review on sustainability transformation roadmaps using project management methodology, Advanced Science Letters, vol. 21, no. 2: pp.133-136. https://doi.org/10.1166/asl.2015.5841

CRAM, 2016, Philosophy, Power of Ideas (CTI Review).

Eskerod, P., \& Huemann, M., 2013, Sustainable development and project stakeholder management: what standards say, International Journal of Managing Projects in Business, vol. 6, no. 1: pp.36-50. https://doi. org/10.1108/17538371311291017

Fernández-Sánchez, G., \& Rodríguez-López, F., 2010, A methodology to identify sustainability indicators in construction project management-Application to infrastructure projects in Spain, Ecological Indicators, vol. 10, pp.1193-1201. https://doi.org/10.1016/j.ecolind.2010.04.009

Gareis, R., Huemann, M., \& Martinuzzi, A., 2009, Relating sustainable development and project management, In IRNOP IX - PMI Research and Education Conference. $11^{\text {th }}-13^{\text {th }}$ October 2009 Berlin.

Gareis, R., Huemann, M., \& Martinuzzi, A., 2013, Project management and sustainable development principles, Project Management Institute, Washington.

Gareis, R., Huemann, M., Martinuzzi, A., Sedlacko, M., \& Weninger, C., 2011, Relating sustainability principles to managing projects: first reflections on a case study project, In IRNOP, Montreal, Canada.

Gartner, 2006, Making the right investment decisions and measuring their value, visited 10-4-2016, Retrieved from http://www.gartner.com/newsroom/id/497088. https://doi.org/10.1007/978-3-540$\underline{71447-7 \quad 7}$

GPM., 2016, The GPM ${ }^{\circledR} P 5^{T M}$ Standard for sustainability in project management, V1.5. visited 10-04-2016

Greenwood, R., Suddaby, R., \& Hinings, C. R., 2002, Theorizing change: the role of professional associations in the transformation of institutionalized fields, Academy of Management Journal, vol. 45, no. 1: pp.58-80. https://doi.org/10.2307/3069285

IPMA, 2015, Code of ethics and professional conduct. https://doi.org/10.1016/j.ijproman.2015.06.008

IPMA, 2015b, Code of ethics and professional conduct - website. visited 10-04-2016 https://doi. org/10.1016/j.ijproman.2015.06.008

IPMA, 2015c, ICB4 - IPMA competence baseline. https://doi.org/10.1002/ejoc.201200111 visited 10-04$\underline{2016}$

IPMA, 2016a, Organisational competence baseline for developing competence in managing by projects.

IPMA, 2016b, Project excellencebaseline for achieving excellence in projects and programmes.

ISOS Group, 2016, Embedding sustainability into your brand's DNA. Retrieved February 16, 2016, from http://isosgroup.com/embedding-sustainability-into-your-brands-dna/ 
U T S

e PRES S

Maltzman, R., \& Shirley, D., 2010, Green Project Management, CRC Press. https://doi.org/10.1201/ ebk1439830017

Marcelino-Sádaba, S., Gonzalez-Jaen, L. F., \& Perez-Ezcurdia, A., 2015, Using project management as a way to sustainability, From a comprehensive review to a framework definition. Journal of Cleaner Production, vol. 99, pp.1-16. https://doi.org/10.1016/j.jclepro.2015.03.020

Martens, M., \& Carvalho, M. M. de., 2016, The challenge of introducing sustainability into project management function: multiple-case studies. Journal of Cleaner Production, vol. 117, pp.29-40. https://doi. org/10.1016/j.jclepro.2015.12.039

Martens, M., \& Carvalho, M. M. de., 2017, Key factors of sustainability in project management context: a survey exploring the project managers' perspective, International Journal of Project Management, vol. 35, no. 6: pp.1084-1102, visited 10-04-2016 https://doi.org/10.1016/j.ijproman.2016.04.004

Muzio, D., Brock, D., \& Suddaby, R., 2013, Professions and institutional change: towards an institutionalist sociology of the professions, Journal of Management Studies, vol. 50, no. 5: pp.699-721. https://doi.org/10.1111/joms.12030

Muzio, D., \& Faulconbridge, J. R., 2013, The global professional service firm: “One Firm” models versus (Italian) distant institutionalized practices, Organization Studies, vol. 34, no. 7: pp.897-925, https://doi. org/10.1177/0170840612470232

PMBOK., 2013, A guide to the project management body of knowledge: PMBOK ${ }^{\circledR}$ Guide (5th edition) (5th ed.).

PMI., 2010, The bottom line on sustainability, Project Management Institute, Inc, 8.

PMI, 2012, PMI strategic plan.

PMI, 2013, PM educational foundation.

PMI, 2016, Sustainability. visited 10-04-2016 Retrieved from http://www.pmi.org/learning/featuredtopics/sustainability

Saad, S., 1997, Integrating the environmental dimension in engineering education, In Environmental Engineering Education (p. 3), World Congress Engineering Education Training.

Sabini, L., 2013, A story of professionalization? The case of project management discipline in Italy. In F. Pennarola \& M. Martinez (Eds.), Empowering society through digital innovations, X Conference of the Italian Chapter of AIS (pp. 1-4), Milan, Italy.

Sabini, L., 2014, The Institutionalization of Project Management. Roma, Italy: Scholars' Press.

Sabini, L., 2016, Integrating sustainability and project management: a systematic literary review, In BAM2016 Conference, Newcastle, UK.

Sabini, L., \& Muzio, D., 2017, The long way to professional recognition: the project management in Italy, International Journal of Managing Projects in Business, vol. 10, no. 4. https://doi.org/10.1108/ ijmpb-02-2017-0011

Sánchez, M., 2015, Integrating sustainability issues into project management, Journal of Cleaner Production, vol. 96, pp.319-330. https://doi.org/10.1016/j.jclepro.2013.12.087

Scott, W. R., 1995, Institutions and organizations, Thousand Oaks, CA: Sage Publications, Inc.

Scott, W. R., 2008, Lords of the dance: professionals as institutional agents, Organization Studies, vol. 29, no. 2: pp.219-238. https://doi.org/10.1177/0170840607088151 
Scott, W. R., Ruef, M., Mendel, P., \& Caronna, C., 2000, Institutional change and healthcare organizations: from professional dominance to managed care, Chicago: University of Chicago Press. https://doi. org/10.1086/320848

Silvius, G., \& Schipper, R. P.J., 2014, Sustainability in project management: a literature review and impact analysis, Social Business, vol. 4, no. 1: pp.63-96. https://doi.org/10.1362/20444081 $\underline{4 \times 13948909253866}$

SustainabilityLearningCenter, 2014, ON-Line Green/Sustainability Project Management, Retrieved October 8, 2014, from http://www.sustainabilitylearningcentre.com/sustainabilitytraining/sustainabilitycourses-at-a-glance/public-courses/152-on-line-greensustainability-project-management

Taylor, T., 2011, Sustainability interventions for managers of projects and programmes.

TheEconomist, 2017, The sustainability summit 2017, Retrieved March 23, 2017, from https://events. economist.com/events-conferences/emea/sustainability-summit-2017/.https://doi.org/10.1007/978-3319-53121-2 33-1

Turner, J. R., Huemann, M., \& Bredillet, C. N., 2010, Perspectives on projects. London: Routledge.

Unruh, G., Kiron, D., Kruschwitz, N., Reeves, M., Rubel, H., \& Meyer Zum Felde, A., 2016, Investing for a sustainable future.

\section{About the Authors}

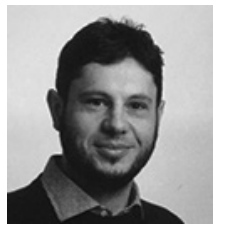

Luca Sabini is a Senior Lecturer at Hertfordshire University Business School. He has been a Marie Skłodowska-Curie Associate Researcher at Newcastle Business School, working on a research project on Sustainability and Project Management. His main research focus is on the study of dynamics of institutionalization of new practices, with particular focus on sustainability within the new occupations (such as Project Management). My broad research interests are related with business organization, Information Technology, Project Management, Sociology of Profession.

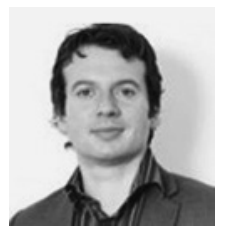

Daniel Muzio is Professor of Professions and Organization at Newcastle University Business School. His research interests include the sociology of the professions, the organisation and management of professional services firms, gender and diversity in professional contexts, and the interplay between professional occupations and professional organisations.

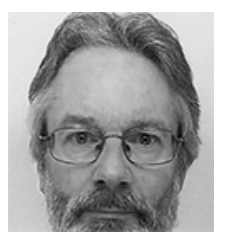

Neil Alderman is a Senior Lecturer at Newcastle University Business School. His research interests include innovation and technology management, product design and development in engineering, innovation in large-scale projects, the management of complex projects and critical perspectives on project management. 


\section{Appendix 1 - Interview protocol}

1. How did you get involved into professional associations?

2. As [role in the association] have you ever bumped in discussions/decisions/projects over sustainability topic?

3. As a practitioner have you ever bumped in discussions/decisions/projects over sustainability topic?

- And as a professional association member?

4. According to academic and practitioners' literature there is a growing link between sustainability and PM, do you share this vision?

5. Do you believe that PM as a profession has a critical role on sustainability topic?

- What is "sustainable project management" in your reflections?

6. Do you recognize any active engagement by professional associations towards sustainability?

7. Provocative answer:

- buying the idea of the need of integration of sustainability and PM, how much weight do you think could have a project manager in bringing the sustainability into the project? In comparison of clients, contractors, consultant designers...

8. Does a gap exist between literature (importance of sustainability in PM) and reality (what is carried out in practice)?

- If so, how can be the gap filled? 